\title{
THE LINK BETWEEN ECONOMIC GROWTH, CRIME AND DETERRENCE MEASURES IN NIGERIA
}

\author{
Adenuga Fabian Adekoya, Ph.D. Student \\ Department of Economics, School of Economics, Finance and Banking, \\ Universiti Utara Malaysia Sintok 06010, Malaysia. \\ adenugaadekoya@gmail.com \\ Nor Azam Abdul Razak \\ Department of Economics, School of Economics, Finance and Banking, \\ Universiti Utara Malaysia Sintok 06010, Malaysia.
}

(Received July 2016; Accepted September 2016)

\begin{abstract}
The level of crime in Nigeria has become devastating and in order to put more sanity into the economy and the country at large, the Government has embarked on different deterrence measures in curbing crime. Thus, this study examined the interaction of deterrence measures with crime in order to see how economic growth was affected when they were used in curbing crime at different instances. That is, the interaction of deterrence measures with crime informed us how they have helped in lowering crime in Nigeria for a better economic growth to subsist. The deterrence measures considered in this work are in line with the rational choice theory being the cost of crime imposed on the society. Furthermore, this study considered data from 1975 to 2013 with the use of autoregressive distributed lag model. Moreover, the results showed that crime dependency on deterrence measures asymmetrically constituted means of lowering economic growth in the country. Hence, this study suggested that prosecution should be well funded and in order to curb crime and improve economic growth in Nigeria. That is, this would afford the country to reduce the congestion of prison inmates and thus, it would discourage long waiting trials.
\end{abstract}

Keywords: crime, growth, deterrence measures and crime dependency.

JEL classification: O10, O40, K42.

\section{Introduction}

The deterrence measures to crime have been widely discussed especially the extent of how they could be used to reduce crime in the society. That is, the functions of deterrence in explaining the behaviour of crime in terms of drifts and forms have shown that deterrence measures were used in curbing crime (Detotto and Pulina, 2012). For instance, the use of police force in fighting crime was discussed in Detotto and Pulina (2012) but, the extent of police performance in curbing crime will depend on the level of cooperation given by the society and the police themselves (Halicioglu, 2012). However, such cooperation could also trim down security expenditure on crime because it has a deterrence effect on crime (Halicioglu, Andrés and Yamamura, 2012) and consequently, it crowds out the 
efficiency of police and judicial institution in society (Quimet, 2012). Besides, Witt and Witte (2000) viewed that prison institution would help in downsizing level of crime and emphatically, the probability of punishment as demonstrated by Bodman and Maultby (1997) indicated that probability of punishment reduced crime significantly. Nevertheless, the roles of deterrence measures have been noted to increase the monetary cost of public and private expenditure. That is, Vigne and Samuels (2012) noted that the growth and cost of prison service are becoming unstainable due to the fiscal resources impact and overcrowding of inmates coupled with the limited resources. In addition, expenses on security might not be a final answer in curbing crime because the distortive tax would cause decreasing gains to security production which may positively affect crime (Mauro and Carmeci, 2007). Moreover, the consequence of increasing public expenditure to fight crime would reduce income growth (Enamorado, López-Calva and Rodríguez-Castelán, 2014). Thus, the extensiveness of this discussion on deterrence has not focused much on how crime dependency on deterrence measures could impact on economic growth with the exception of Goulas and Zervoyianni (2015) that considered the interaction of crime with public spending. Therefore, this study intends to ascertain whether crime activities is detrimental to economic growth, and especially to determine whether social cost of crime in terms of prosecution and internal security expenditure impose on the country is deficient in promoting economic growth in Nigeria.

\section{Literature Review}

Empirically, studies on the crime dependency on deterrence measures have demonstrated a positive capability of crime interaction with deterrence measures. The work of Svensson (2013) focused on the use of morality interacting with deterrence on offending and concluded that offending was significantly affected by morality dependency on deterrence especially when the morale is low. Similarly, Batabyal and Chowdhury (2015) considered the interaction of corruption with financial development in development studies of income inequality. The study found that the interaction of corruption with financial development was positively and well impacted on the various income levels in cross-country study of 30 . Likewise, in the interaction of corruption with income on savings; Abu, Abd Karim and Aziz (2015) revealed that corruption dependency on income produced a significant adverse effect on savings rates. That is, low saving rates among West African nations was due to corruption interacting with income and it has encouraged high-income gap in the sub-region. In addition, Goulas and Zervoyianni (2015) expressed crime dependency on the uncertainty of the market, low-employment and strain on the public sector resources in the course of 
examining crime and growth. The main interest is the strain on the public resources which crime causes more public funds to secure safety for the public. The study showed that interacting crime with public resources significantly reduces the growth of the economy. However, the feature of offences in any forms interacting with policy and macroeconomic variables by these previous works have provided more flesh to the literature. But, a gap still subsists in the literature especially, in the area of interacting crime or offences with deterrence measures indicated in the rational choice theory which includes punishment and prosecution.

The rational choice theory offered that punishment, conviction, and prosecution are the costs imposed on the society by crime; there is a possibility that these costs of crime would make the loss of wealth happened in a society (Becker, 1968). That is, additional resources would be required by the society to pursue the implementation of these deterrence measures if the crime is to be reduced. Besides, the society needs improvement in wealth to avert income-gap and failure to have income-gap reduced, it may serve as incentives for crime (Ehrlich, 1973). However, allowing crime to pervade may mean harms because poverty income may be worse, simply that resources meant for wealth creation would be diverted to combat crime. Moreover, the ability of the society in fighting crime would require more enforcement of law through the police which ultimately depends on resources allocated to such task (Stigler, 1974). Nevertheless, where there is an inability of the public to adequately finance the enforcement, the theory encouraged punishment in terms of fine and imprisonment. While fine would increase the public wealth, imprisonment would decrease the purse of the society (Becker, 1968). But in most cases, not all crimes have the benefit of fine and as such offenders were imprisoned by prosecution and conviction in which evidence have it that public funds were used in financing prison services (Stigler, 1974). Then, if deterrence measures were a burden to the society, how does crime dependency on deterrence measures affect economic growth in a society especially, Nigeria?

\subsection{The situation of crime deterrence measures in Nigeria}

The existence of crime in Nigeria and its measures adopted in curbing crime may have effects on the development of the country. But, the main concern here is to see how these efforts adopted in attempts to curb crime were able to improve economic growth. That is, crime and its deterrence measures have been examined individually and theoretically, they indeed have an impact on the society. Notwithstanding, what may like happened if the crime dependency on deterrence measures is analyzed on development and growth. Also, economic approach to crime tells less of this analytically but assumes that it is likely to ensure better 
situation in society. Moreover, the situation in Nigeria on crime dependency on prosecution and public expenditure on internal security are outlined subsequently. In the scene of crime combats in Nigeria, the rank and file of the Nigerian Police Force has witnessed substantial growth for some years. The numbers of personnel were 137,734 and 137,000 officers in 1993 and 1999 respectively. In 2003, 2006 and 2007 the estimated figure stood at 260,000, 319,872 and 309,483 accordingly. By 2009 and 2010, the Police Force had a total talent of 345,023 and 360,000 police officers (Nigeria Bureau of Statistics (NBS), 2011; Network on Police Reform in Nigeria, 2010). Meanwhile, the Nigeria Police Force has been performing the task of policing in the country where there is poor infrastructure, political insecurity, fragile institutions, diversity in ethnic and religion accidental strife (Network on Police Reform in Nigeria, 2010). The performance of the Nigeria Police Force is a bit encouraging when noting the puny circumstance in which a Police Officer carried out the policing task. This is because the insubstantial fund given to the Police Force has made them be in possession of inadequate and obsolete equipment and it has exposed most police officers to hazard at the detriment of violent criminals who were well equipped (Ojedokun, 2014). However, the efforts of the Nigeria Police Force were able to record crime cases, prosecute those cases and have cases closed upon investigation. For instance, in the total number of crimes recorded cases in the period of 2008 and 2011; cases prosecuted remains $56.92 \%$ in 2008 and decreased to $36.71 \%$ and thereafter increased to $36.75 \%$ in 2010 and 2011 accordingly. In addition, the number of cases closed was $4.43 \%$ in 2008; this increased to $12.77 \%$ in 2010 and then reduced to $9.76 \%$ in 2011 . More so, the number of cases pending increased from $27.80 \%$ in 2008 to $29.09 \%$ in 2010 and then it increased to $30.32 \%$ in 2011 . Nevertheless, taking the entire crime prosecution rate per 100,000 population in the early return of the present democratic dispensation with $78.98 \%, 80.02 \%$ and $83.51 \%$ in 2000,2001 and 2002 respectively (REPHRSE). The crime prosecution rate becomes worse in 2008 with $34.02 \%$ which furthermore worsens in 2012 with $16.70 \%$ even though it got up to $25.58 \%$ in 2013 . On the contrary, growth has witnessed continuous reduction from 38.89\% and $41.57 \%$ in 2000 and 2002 to $14.65 \%$ in 2008 and went further to $10.81 \%$ and $8.51 \%$ in 2012 and 2013 as presented in Figure 1.

Likewise, owing to the high crime occurrence in Nigeria, Badiora, Okunola and Ojewale (2014) and Ojedokun (2014) agreed in their various studies that crime needs serious control within and across the country. With this, the Federal Government ensured that the expenditure on internal security was increased from \$9.8 billion Naira in 2005 to $\$ 253.7$ billion Naira and $\$ 420.6$ billion Naira in 2009 and 2012 respectively.

Studia Universitatis "Vasile Goldis" Arad. Economics Series Vol 26 Issue 4/2016 ISSN: 1584-2339; (online) ISSN: $2285-3065$

Web: publicatii.uvvg.ro/index.php/studiaeconomia.Pages $24-40$ 


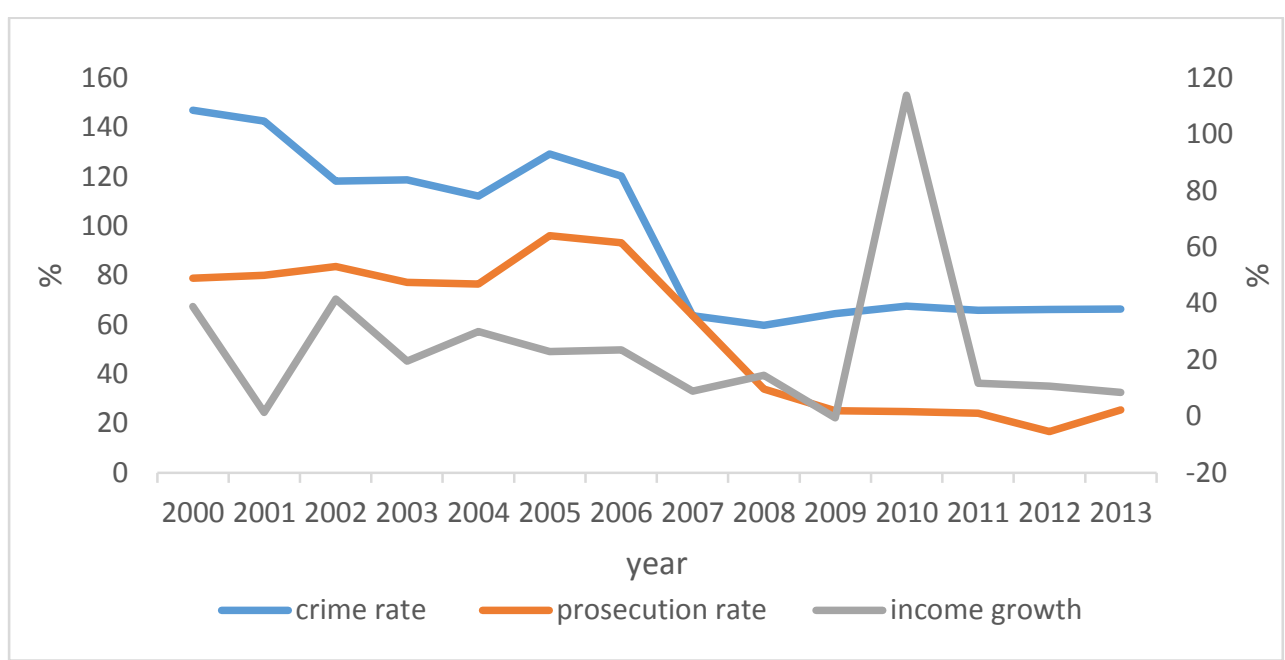

Figure 1: Crime dependency on prosecution and growth Sources: Authors Compilation based on NBS, 2012; CBN, 2013; World Bank Indicator, 2014

Similarly, there was an increase in expenditure on the States judiciary from 26.3 billion Naira in 2005 to $\$ 52.1$ billion Naira and reduced to $\$ 41.6$ billion Naira in 2009 and 2012 respectively. That is, the Internal Security Expenditure \% of Total Expenditure increased from 5.47\% in 2005 to $7.34 \%$ and $9.13 \% 2009$ and 2012 accordingly, but the state judiciary expenditure increased from $1.44 \%$ in 2005 to $1.53 \%$ in 2009 and got reduced to $0.90 \%$ in 2012 (Central Bank of Nigeria (CBN), 2013). Also, it is commendable to increase public resources to fight crime for peace and stability in the country but in the relation to growth, growth has not shown much appreciation ever since 2010 till 2013 based on available data. Moreover, the crime fighting through public expenditure on internal security is doubted if it has meaningfully contributed to growth in the country as presented in Figure 2.

In view of the above, the study of crime dependency on measures of deterrence is considered as important because it would provide us the statistical evidence of crime interaction with deterrence measures of prosecution and public internal expenditure on security which is lacking in the literature. Moreover, these various deterrence measures interacting with a crime may perhaps tell us what happened to economic growth and development that have not received much attention in the literature especially in Nigeria. 


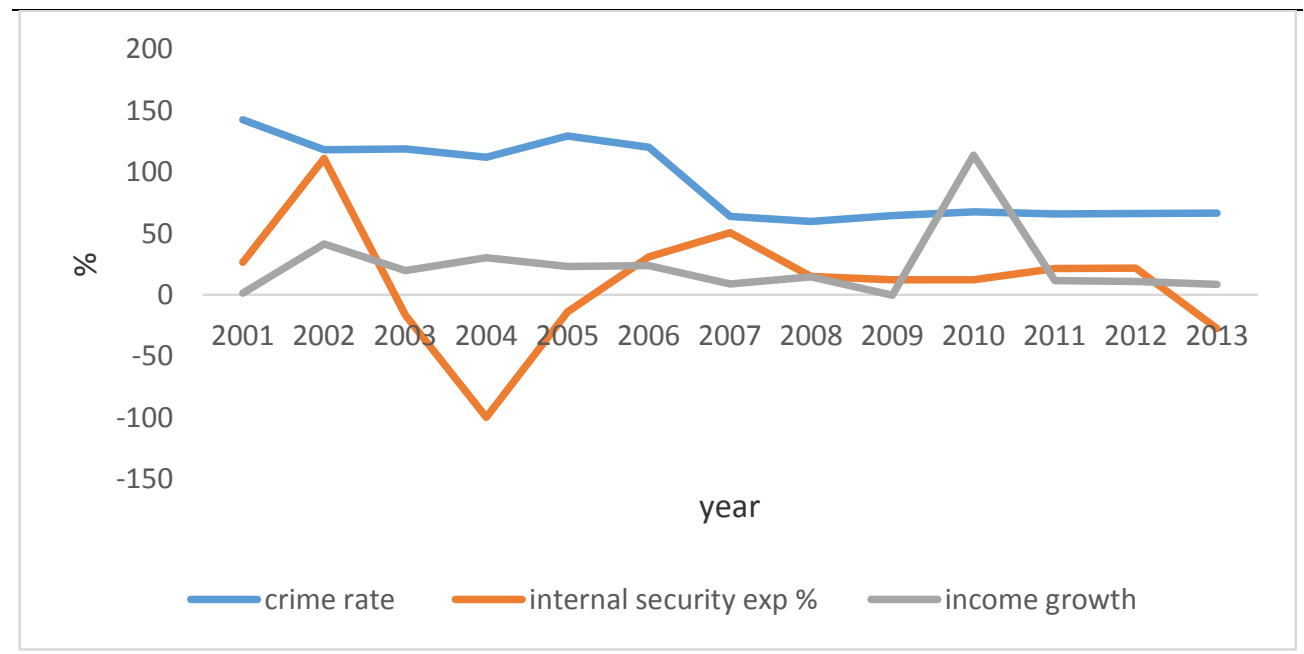

Figure 2: Crime dependency on Expenditure and growth

Sources: Author compilation based on NBS, 2012, CBN, 2013; World Bank Indicator, 2014

Also, it would help in policy direction on the approach to combat crime when formulating policy; that is, on how to use public resources to achieve crime reduction and enhance economic growth and development in the country. Hence, the remaining part of the study considered the methodology, results, and conclusion.

\section{Methodology}

\subsection{Data}

Data for real gross domestic per capita was obtained from the World Bank Indicator (2014) while data for crime and prosecution were obtained from the Nigeria Police and Nigeria Bureau of Statistics (NBS). Education enrolment was mainly from the NBS, the public expenditure on internal security and gross fixed capital formation was from the Central Bank of Nigeria. All-time series data used in this study starts from 1975 to 2013.To examine the crime dependency on deterrence measures, this work interacts crime with public expenditure on internal security and prosecution by taking their residual after estimating for their ordinary least square. Moreover, the use of residuals to replace that interaction was to avoid the problem of multicollinearity. A similar approach was also considered by Abu, Abd Karim and Aziz (2015) when corruption interacted with income. Moreover, the descriptive statistics and their definition are presented in Table 1. 
Adekoya A.F., Razak N.A.A.(2016)

The link between economic growth, crime and deterrence measures in Nigeria

\begin{tabular}{|l|r|r|r|r|r|l|}
\hline \multicolumn{7}{c|}{ Table 1: Descriptive statistics and definition of variables } \\
\hline Variables & \multicolumn{1}{c|}{ Obs. } & \multicolumn{1}{c|}{ Mean } & \multicolumn{1}{c|}{ Std. Dev. } & \multicolumn{1}{l|}{ Min. } & \multicolumn{1}{l|}{ Max. } & Definition \\
\hline$R G P C$ & 39 & 71331.27 & 125418.1 & 360.9 & 466606 & $\begin{array}{l}\text { Real Gross Domestic Product } \\
\text { per capita }\end{array}$ \\
\hline$C R$ & 39 & 231.17 & 121.38 & 59.8 & 474.3 & $\begin{array}{l}\text { Crime recorded per } 100,000 \\
\text { population }\end{array}$ \\
\hline$G F C F$ & 39 & 10.60 & 5.90 & 3.6 & 24 & Gross fixed capital formation \\
\hline$E E S$ & 39 & 4284875 & 2448178 & 705516 & 9835240 & $\begin{array}{l}\text { Enrolment of secondary } \\
\text { education }\end{array}$ \\
\hline$U N E$ & 39 & 8.93 & 6.91 & 1.8 & 27.4 & Unemployment rate \\
\hline$P E S$ & 39 & 4.79 & 3.02 & 0.3 & 13.6 & Public exp. on internal security \\
\hline$P R$ & 39 & 132.52 & 84.11 & 16.7 & 324.9 & Prosecution per population \\
\hline$C R * P E S$ & 39 & -146.92 & 567.52 & -828.59 & 1813.88 & $\begin{array}{l}\text { Residual of CR and PES } \\
\text { interaction }\end{array}$ \\
\hline$C R * P R$ & 39 & -4920.29 & 12916.12 & -19617.66 & 46396.23 & $\begin{array}{l}\text { Residual of CR and PR } \\
\text { interaction }\end{array}$ \\
\hline
\end{tabular}

\subsection{Model Specification}

In order to analyse the variable relationships in this study, this study employed the exogenous growth model in Mauro and Carmeci (2007) by adding public expenditure on internal security $\left(P E S_{i}\right)$ and prosecution $\left(P R_{i}\right)$ to the model. The growth model focused on crime as a variable affecting economic growth. Besides, economic growth was measured with the Real GDP per capita $\left(R G P C_{i}\right)$. Also, accumulation was measured by secondary education enrolment $\left(E E S_{i}\right.$ and gross fixed capital formation $\left(G F C F_{i}\right)$ as a $\%$ to real GDP. Unemployment $\left(U N E_{i}\right)$ was considered to see the effect of labour policy on growth in the model due to its relationship with crime. The public expenditure on internal security $\left(P E S_{i}\right)$, and prosecution $\left(P R_{i}\right)$ were deterrence variables considerably based on the theory of rational choice (Becker, 1968). In addition, in place of crime of homicide discussed in Mauro and Camerci (2007), this study considered overall crime rate $\left(C R_{i}\right)$. Thus, two growth models were specified and presented in equation 1 and 2. In model 1 and $2 ; \pi_{1}$ and $\pi_{2}$ are constant parameters; $\beta_{1}$ and $y_{1}$ are the elasticity effects of crime and unemployment variables on growth respectively and they are expected to be negative. In addition, $\beta_{2}$ and $y_{2}, \beta_{3}$ and $y_{3}$ show the positive effect of gross fixed capital formation and education on growth correspondingly. Also $\beta_{5}$ and $y_{5}$ describe the impact of public expenditure on internal security and prosecution on growth in that order. Moreover, $\beta_{6}$ and $\mathrm{y}_{6}$ describes how the interaction of crime with public expenditure on internal security and prosecution would affect growth accordingly. Hence, $\varepsilon_{\mathrm{t}}$ and $\mu_{\mathrm{t}}$ shows the residual in each of the model and $\ln$ is the $\log$ of variables.

$$
\begin{aligned}
\ln R G P C_{t}=\pi_{1} & +\gamma_{1} C R_{t}+\gamma_{2} \ln G F C F_{t}+\gamma_{3} \ln E E S_{t}+\gamma_{4} \ln U N E_{t} \\
& +\gamma_{5} P R_{t}+\gamma_{6} C R * P R_{t}+\varepsilon_{t}
\end{aligned}
$$




$$
\begin{aligned}
\ln R G P C_{t}=\pi_{2} & +\beta_{1} C R_{t}+\beta_{2} G F C F_{t}+\beta_{3} E E S_{t}++\beta_{4} U N E_{t} \\
& +\beta_{5} P E S_{t}+\beta_{6} C R * P E S_{t}+\mu_{t}
\end{aligned}
$$

\section{Analysis of Results}

\subsection{Result of unit root test}

Conventionally, previous studies have affirmed that time series data must be put to stationarity test in order to avoid spurious regression. The essence of the test is to see if the series are not having a unit root as a precondition for examining the joint movement of series in a model (Engle and Granger, 1987).

\begin{tabular}{|c|c|c|c|c|c|}
\hline \multirow{3}{*}{ variables } & \multicolumn{2}{|c|}{ Augmented Dickey-Fuller (ADF) } & \multicolumn{2}{|c|}{ Phillip-Perron (PP) } & \multirow{3}{*}{ 气ֶ气 } \\
\hline & LEVEL & $1^{\text {ST }}$ DIFFERENCE & LEVEL & $1^{\text {ST }}$ DIFFERENCE & \\
\hline & Intercept and trend & Intercept and trend & Intercept and trend & Intercept and trend & \\
\hline $\ln R G P C$ & -2.198 & $-5661 * * *$ & -2.198 & $-5661 * * *$ & $\mathrm{I}(1)$ \\
\hline$C R$ & -2.488 & $-4.445 * * *$ & -2.462 & $-7.849 * * *$ & $\mathrm{I}(1)$ \\
\hline$G F C F$ & -1.415 & $-5.649 * * *$ & -1.285 & $-10.552 * * *$ & $\mathrm{I}(1)$ \\
\hline $\ln G F C F$ & -0.829 & $-5.820 * * *$ & -1.250 & $-7.941 * * *$ & $\mathrm{I}(1)$ \\
\hline EES & -1.251 & $-6.317 * * *$ & -3.021 & $-10.757 * * *$ & $\mathrm{I}(1)$ \\
\hline $\ln E E S$ & $-3.307 *$ & $-7.281 * * *$ & $-3.327 *$ & $-7.226 * * *$ & $\mathrm{I}(0)$ \\
\hline$U N E$ & -0.902 & $-4.374 * * *$ & -1.049 & $-4.577 * * *$ & $\mathrm{I}(1)$ \\
\hline $\ln U N E$ & -1.454 & $-5.323 * * *$ & -1.577 & $-5.328 * * *$ & $\mathrm{I}(1)$ \\
\hline$P R$ & $-4.587 * * *$ & $-6.305 * * *$ & $-4.708 * * *$ & $-10.885^{* * *}$ & $\mathrm{I}(0)$ \\
\hline PES & $-5.077 * * *$ & $-8.227 * * *$ & $-6.322 * * *$ & $-8.188 * * *$ & $\mathrm{I}(0)$ \\
\hline$C R \times P R$ & -2.095 & $-5.929 * * *$ & $-3.515 *$ & $-9.790 * * *$ & $\mathrm{I}(0)$ \\
\hline$C R \times P E S$ & $-4.489 * * *$ & $-5.822 * * *$ & $-5.639 * * *$ & $-7.644 * * *$ & $\mathrm{I}(0)$ \\
\hline
\end{tabular}

Table 2: Result of the Unit Root Tests

NOTE: the figures reported are t-ratio that possessed the p-values of MacKinnon (1996) one-sided at various level of significant. The level of significant was asterisked (*) at 10\%; $(* *)$ at $5 \%$ and $(* * *)$ at $1 \%$.

However, this study made those non-stationary to stationary at the level $\mathrm{I}(0)$ and first difference I(1) with the aid of Augmented Dickey-Fuller (ADF) and Phillip and Perron unit roots test. Also, these tests were done using automatic based on Schwartz Bayesian criterion with maximum lag9 for ADF; and Newey-West automatic using Bartlett kernel for PP. Hence, the null hypothesis is that the series has a unit root and the rejection of this null hypothesis is that series is not having a unit root, that is series is stationary based on the MacKinnon (1996) as specified in E-view 9.5.

\subsection{Result of bounds tests approach}

Owing to the result of the unit root tests, this study found that series were made stationary at $\mathrm{I}(0)$ and $\mathrm{I}(1)$. In estimating the co-integration for mixed series with 
$\mathrm{I}(0)$ and I(1) integration, Pesaran, Smith and Shin (2001) proposed the autoregressive distributed lag model (ARDL) as an appropriate estimation. This is because another co-integration method only considered series with $\mathrm{I}(1)$ and moreover, ARDL produced no negative impact upon the use of small sample size (Narayan, 2005). Moreover, the use of ARDL presupposed that variables are made dynamic with lag; that is, equation 1 and 2 were transformed into a dynamic version as indicated in equation 3 and 4 . Also, to transform these equations 1 and 2 into a dynamic version, this study used Akaike Information Criterion (AIC) due to small sample size to determine the appropriate lag length selection criteria which are presented in Table 3. This is because the selection of lag criteria would minimise the autocorrelation in the residual (Shyh-Wei, 2009). Thus, this study specified models 3 and 4 based on Akaike Information Criterion using an automatic lag selection of 2 and 1 respectively in E-views 9.5. In addition, each of the models was run using restricted intercept and no trend (Pesaran et al., 2001). However, the bound test was used to determine the existence of cointegration in the long-run using the F-test statistic. This F-statistic tested the joint significance of the coefficients at one period of lag as shown in equation 3 and 4 . That is, null hypothesis of no cointegration is that $\mathrm{H}_{0}: \mathrm{y}_{1}=\mathrm{y}_{2}=\mathrm{y}_{3}=\mathrm{y}_{4}=\mathrm{y}_{5}=\mathrm{y}_{6}=\mathrm{y}_{7}=0$ and the alternate is $\mathrm{H}_{1}: \mathrm{y}_{1} \neq \mathrm{y}_{2} \neq \mathrm{y}_{3} \neq \mathrm{y}_{4} \neq \mathrm{y}_{5} \neq \mathrm{y}_{6} \neq \mathrm{y}_{7} \neq 0$, where at least one of the $\mathrm{y}_{1}$ to $\mathrm{y}_{7} \neq$ 0 (implies cointegration); similarly for $\beta_{1}$ to $\beta_{7}$.

$$
\begin{aligned}
\Delta \ln R G P C_{t}=\pi_{1}+ & \gamma_{1} \ln R G P C_{t-1}+\gamma_{2} C R_{t-1}+\gamma_{3} \ln G F C F_{t-1}+\gamma_{4} \ln E E S_{t-1} \\
& +\gamma_{5} \ln U N E_{t-1}+\gamma_{6} P R_{t-1}+\gamma_{7} C R * P R_{t-1}+\sum_{i=1}^{p} \tau_{1} \Delta \ln R G P C_{t-i} \\
& +\sum_{i=0}^{p} \tau_{2} \Delta C R_{t-i}+\sum_{i=0}^{p} \tau_{3} \Delta \ln G F C F_{t-i}+\sum_{i=0}^{p} \tau_{4} \Delta \ln E E S_{t-i} \\
& +\sum_{i=0}^{p} \tau_{5} \Delta \ln U N E_{t-i}+\sum_{i=0}^{p} \tau_{6} \Delta P R_{t-i}+\sum_{i=0}^{p} \tau_{7} \Delta C R * P R_{t-1}+\varepsilon_{t} \\
\Delta \ln R G P C_{t}=\pi_{2}+ & \beta_{1} \ln R G P C_{t-1}+\beta_{2} C R_{t-1}+\beta_{3} G F C F_{t-1}+\beta_{4} E E S_{t-1}+\beta_{5} U N E_{t-1} \\
& +\beta_{6} P E S_{t-1}+\beta_{7} C R * P E S_{t-1}+\sum_{i=1}^{p} \alpha_{1} \Delta \ln R G P C_{t-i} \\
& +\sum_{i=0}^{p} \alpha_{2} \Delta C R_{t-i}+\sum_{i=0}^{p} \alpha_{3} \Delta G F C F_{t-i}+\sum_{i=0}^{p} \alpha_{4} \Delta E E S_{t-i} \\
& +\sum_{i=0}^{p} \alpha_{5} \Delta U N E_{t-i}+\sum_{i=0}^{p} \alpha_{6} \Delta P E S_{t-i}+\sum_{i=0}^{p} \alpha_{7} \Delta C R * P E S_{t-1}+\mu_{t}
\end{aligned}
$$


The criteria for a long-run relationship is that the F-statistic test value must not be below or in between the $\mathrm{I}(0)$ and $\mathrm{I}(1)$ bounds but must be above $\mathrm{I}(1)$. In this study, the rejection of the null hypothesis that no cointegration exists was rejected at the appropriate level of significance. Thus, the result of the bound test was presented in Table 4 which showed that all the models were cointegrated at $5 \%$.

Table 3: Summary of the selected lagged criteria

\begin{tabular}{lllllll} 
Models & LogL & AIC* & BIC & HQ & Adj. R-sq & Specification \\
\hline Equation 1 & 26.539 & -0.515 & 0.224 & -0.254 & 0.995 & ARDL $(1,2,0,1,2,2,2)$ \\
Equation 2 & 19.364 & -0.334 & 0.225 & -0.135 & 0994 & ARDL $(1,1,1,1,0,1,1)$ \\
\hline
\end{tabular}

Table 4: Bounds test for the existence of cointegration

\begin{tabular}{|c|c|c|c|c|c|}
\hline Models & F-Statistic & Critical & lues at $\mathrm{v}$ & us leve & signific \\
\hline & & $\begin{array}{l}10 \% \text { at } \\
\mathrm{I}(0)\end{array}$ & $\begin{array}{l}10 \% \text { at } \\
\mathrm{I}(1)\end{array}$ & $\begin{array}{l}5 \% \text { at } \\
\mathrm{I}(0)\end{array}$ & $\begin{array}{l}5 \% \text { at } \\
\mathrm{I}(1)\end{array}$ \\
\hline $\begin{array}{l}\ln R G P C=f(\mathrm{cr}, \ln (\mathrm{gfcf}), \ln (\mathrm{ees}) \\
\ln (\mathrm{une}), \mathrm{pr}, \mathrm{cr} * \mathrm{pr})\end{array}$ & 7.985 & 1.99 & 2.94 & 2.27 & $3.28 * *$ \\
\hline $\begin{array}{l}\ln R G P C=f(\mathrm{cr}, g f c f, \text { ees, } \\
\text { une, pes, cr } * \text { pes })\end{array}$ & 6.274 & & & & \\
\hline
\end{tabular}

Note: the $*$ indicates the bound at which each model was significant in order to show if there is cointegration.

\subsection{Result of diagnostic test}

In showing that the results obtained in this study were highly robust, the estimation of the ARDL was put to the following diagnostic tests which were the normality test, functional test, serial correlation test, heteroscedasticity test, and stability tests. The normality test of Jarque-Bera showed that model 1 and 2 passed the test. Also, the two models specified in this study passed the tests of LM of Breusch-Godfrey serial correlation using both the F-statistic and Observed $\mathrm{R}^{2}$ probabilities values which were above $5 \%$ level of significance. In addition, the study found no presence of heteroskedasticity in all the models with the aid of Breusch-PaganGodfrey heteroskedasticity test at 5\% significance level. However, in ensuring that the parameters had an inconstant form for all coefficients and variances of the disturbance terms especially in a long-run relationship (Pesaran and Pesaran, 2009), this study tested the stability of cumulative sum and the cumulative sum of squares. The results of the cumulative sum and the cumulative sum of squares showed in Figure 4 and 5 that the two models passed the stability tests at 5\% level of significance.

Studia Universitatis "Vasile Goldis" Arad. Economics Series Vol 26 Issue 4/2016 ISSN: 1584-2339; (online) ISSN: $2285-3065$ 
Adekoya A.F., Razak N.A.A.(2016)

The link between economic growth, crime and deterrence measures in Nigeria

\begin{tabular}{|c|c|c|c|c|c|}
\hline \multicolumn{6}{|c|}{ Table 5: Diagnostic test for the ARDL long-run relationship } \\
\hline & & \multicolumn{2}{|c|}{ Model 1} & \multicolumn{2}{|c|}{ Model 2} \\
\hline \multirow{2}{*}{$\begin{array}{l}\text { Jarque-Bera } \\
\text { Kurtosis }\end{array}$} & & \multicolumn{2}{|l|}{$1.411(0.493)$} & \multicolumn{2}{|l|}{$1.069(0.585)$} \\
\hline & & 2.043 & & 3.181 & \\
\hline \multirow{2}{*}{$\begin{array}{l}\text { Ramsey's RESSET } \\
\text { Test }\end{array}$} & t-statistic & $0.890(19)$ & $(0.384)$ & $1.155(24)$ & $(0.259)$ \\
\hline & F-statistic & $0.792(1,19)$ & $(0.384)$ & $1.334(1,24)$ & $(0.259)$ \\
\hline \multirow[t]{2}{*}{ LM Test } & F-statistic & $0.801(2,18)$ & $(0.464)$ & $0.100(2,23)$ & $(0.904)$ \\
\hline & $\mathrm{Obs}^{*} \mathrm{R}^{2}$ & $3.025(2)$ & $(0.220)$ & $0.328(2)$ & $(0.848)$ \\
\hline \multirow[t]{2}{*}{ BPG Test } & F-statistic & $1.041(16,20)$ & $(0.459)$ & $1.666(12,25)$ & $(0.136)$ \\
\hline & Obs* $\mathrm{R}^{2}$ & $16.819(16)$ & (0.397) & $16.887(12)$ & (0.153) \\
\hline
\end{tabular}

Note: All p-values are in parenthesis and italic with three decimals.

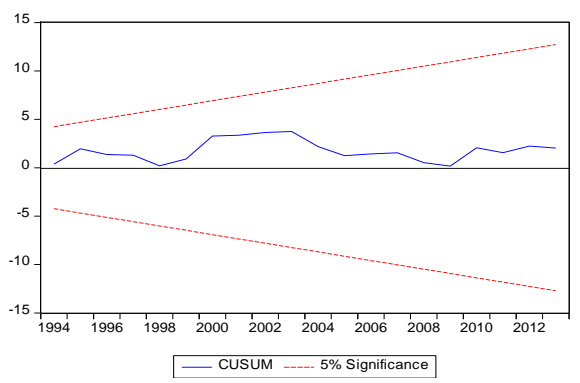

a.

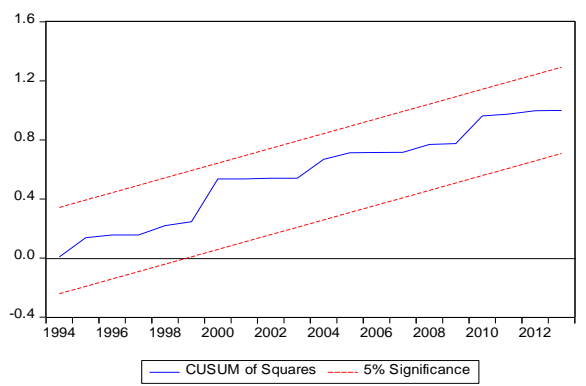

b.

Figure 4: Stability test for model 1

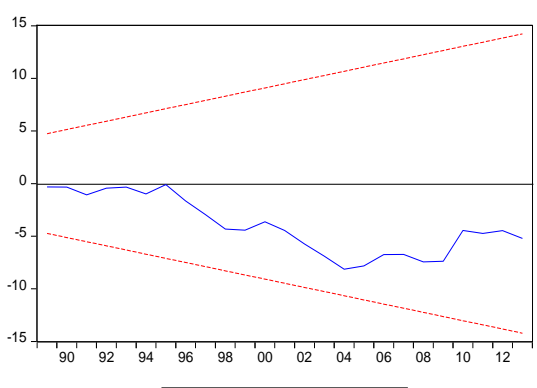

- CUSUM ---. $5 \%$ Significance

a.

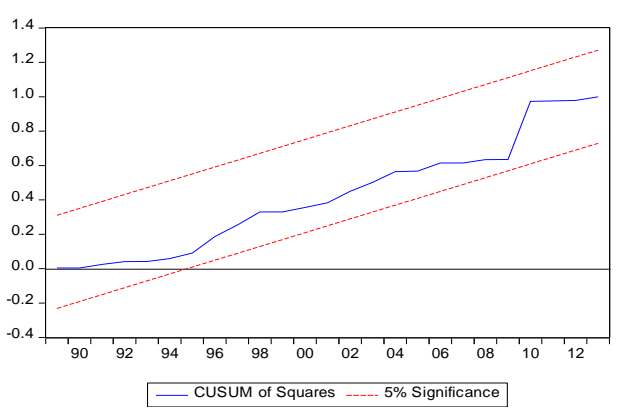

b.

Figure 5: Stability test for model 2

\subsection{Results of the long-run and short-run estimation}

In the first model where the crime interacted with prosecution rate, the results revealed that crime is inversely affecting economic growth significantly at $1 \%$ in the long-run. That is, an increase in $1 \%$ of crime rate would cause $0.021 \%$ decrease change in economic growth. This result is in line with the theory of rational choice as explained by Becker (1968) that crime is detrimental to the welfare of the

34 DE GRUYTER OPEN
Studia Universitatis "Vasile Goldis" Arad. Economics Series Vol 26 Issue 4/2016 ISSN: 1584-2339; (online) ISSN: 2285 - 3065

Web: publicatii.uvvg.ro/index.php/studiaeconomia.Pages $24-40$ 
society. Moreover, the inverse relationship between crime and economic growth supports the work of Mauro and Carmeci (2007) on growth exogenous model. In the accumulation of resources, only education is significant at $1 \%$ level of significance. The more people were educated and high knowledge accumulation takes place in them the more there would be growth in the economy. This result supports Pribac, Angelina and Blaga (2016) and Dima (2014). Moreover, unemployment impacts on the growth of the economy negatively at $1 \%$ level of significance and would reduce economic growth by $9.35 \%$ when the level of unemployment is increased in the country by $10 \%$. In addition, the rate of prosecution enhances economic growth positively at 5\% level of significance; this result supports the theory of rational choice that prosecution of criminals would discourage crime in the society, which would generate a lot of welfare in the society (Becker, 1968). Hence, the interactions of crime with prosecution yield a positive relationship with economic growth at 5\% level of significance. However, in spite of this positive relationship between interactions of crime with prosecution and growth, the use of prosecution to fight crime in society may not break the chain of poor growth in the country. This is because the result of crime depending on the prosecution in affecting economic growth yields a negative result through the mean. That is, coefficients $\mathrm{y}_{1}+\mathrm{y}_{0}$ with mean of prosecution are equal to -0.00154 which translates that the use of prosecution in Nigeria to combat crime has not helped in improving economic growth in the country. Thus, this provides another asymmetric source that crime damages economic growth in Nigeria.

The second model shows that in the long-run, crime negatively impacts on economic growth at $1 \%$ level of significance; that is, a $10 \%$ increase in crime would reduce the growth of the economy by $0.8 \%$. Here, the two proxies for accumulation were significant at $1 \%$. That is, while gross fixed capital formation negatively affects economic growth, education affects economic growth positively. The result on education supports Mauro and Carmeci (2007) but, the result of gross fixed capital formation was in contrary to the positive result obtained in Mauro and Carmeci (2007). This negative result between gross fixed capital formation and economic growth portrays the crime situation in the country which has encouraged the destruction of properties and capital flight out of the country (Federal Ministry of Finance, Nigeria, 2014 and Japan International Corporation Agency, 2011). Thus, the Federal Government of Nigeria has opined that crime related matters destroyed investment in the country while Japan International Corporation Agency noted that capital flight in the country has increased alongside with the level of corruption of public office holders in the country. Moreover, public expenditure on internal security affects economic growth negatively at $10 \%$ level of significance. That is, the use of public fund to reduce crime affects the growth of the economy 
by $0.211 \%$ each time it is increased by $1 \%$. Meanwhile, the interaction of crime with public expenditure on internal security yields a positive impact on economic growth at $10 \%$. But in considering the mean of public expenditure on internal security with $\beta_{1}$ and $\beta_{5}$, the crime reduction through public expenditure on internal security has a negative value of -0.0031 .

Table 6: Estimates of the growth models in the long-run and short-run relationship using ARDL Model

\begin{tabular}{|c|c|c|c|}
\hline \multicolumn{4}{|l|}{ Long-run Estimation } \\
\hline Variables & Model 1 & Variables & Model 2 \\
\hline $\mathbf{C R}$ & $\begin{array}{r}-0.021 * * * \\
(-6.509)\end{array}$ & CR & $\begin{array}{r}-0.010 * * * \\
(-6256)\end{array}$ \\
\hline LOG(GFCF) & $\begin{array}{r}-0.007 \\
(-0.039)\end{array}$ & EES & $\begin{array}{r}0.000001 * * * * \\
(5.241)\end{array}$ \\
\hline LOG(EES) & $\begin{array}{r}2.621 * * * \\
(4.642)\end{array}$ & GFCF & $\begin{array}{r}-0.077 * * * \\
(-3.935)\end{array}$ \\
\hline LOG(UNE) & $\begin{array}{r}-0.935^{* * * *} \\
(-3.516)\end{array}$ & UNE & $\begin{array}{r}0.005 \\
(0.187)\end{array}$ \\
\hline PR & $\begin{array}{r}0.009 * * \\
(2.178)\end{array}$ & PES & $\begin{array}{l}-0.211^{*} \\
(-1.813)\end{array}$ \\
\hline XCPR & $\begin{array}{r}0.000043^{* *} \\
(2.423)\end{array}$ & XCPES & $\begin{array}{r}0.001480 * \\
(2.078)\end{array}$ \\
\hline Constant & $\begin{array}{r}-24.380 * * \\
(-2.714) \\
\end{array}$ & $\mathbf{C}$ & $\begin{array}{r}10.784 * * * \\
(14.406) \\
\end{array}$ \\
\hline \multicolumn{4}{|l|}{ Short-run Estimates } \\
\hline Variables & Model 1 & Variables & Model 2 \\
\hline $\mathbf{D}(\mathbf{C R})$ & $\begin{array}{r}-0.003 * * \\
(-2.654)\end{array}$ & $\mathbf{D}(\mathbf{C R})$ & $\begin{array}{r}-0.0016^{* *} \\
(-2.217)\end{array}$ \\
\hline $\mathbf{D}(\mathbf{C R}(-\mathbf{1}))$ & $\begin{array}{r}0.004 * * \\
(2.511)\end{array}$ & D(EES) & $\begin{array}{r}0.000 * * * \\
(4.125)\end{array}$ \\
\hline DLOG(GFCF) & $\begin{array}{r}0.052 \\
(0.502)\end{array}$ & D(GFCF) & $\begin{array}{r}-0.007 \\
(-0.688)\end{array}$ \\
\hline DLOG(EES) & $\begin{array}{r}0.603 * * \\
(3.555)\end{array}$ & D(UNE) & $\begin{array}{r}0.001 \\
(0.067)\end{array}$ \\
\hline DLOG(UNE) & $\begin{array}{r}-0.035 \\
(-0.345)\end{array}$ & D(PES) & $\begin{array}{r}-0.012 \\
(-0.699)\end{array}$ \\
\hline DLOG(UNE(-1)) & $\begin{array}{r}0.216^{* * *} \\
(2.105)\end{array}$ & D(XCPES) & $\begin{array}{r}0.0001 \\
(1.288)\end{array}$ \\
\hline D(PR) & $\begin{array}{r}0.005 * * * \\
(4.574)\end{array}$ & CointEq(-1) & $\begin{array}{r}-0.376 * * * \\
(-7.636)\end{array}$ \\
\hline D(PR(-1)) & $\begin{array}{r}0.003 * * * \\
(3.119)\end{array}$ & & \\
\hline D(XCPR) & $\begin{array}{r}-0.000 \\
(-1.545)\end{array}$ & & \\
\hline D(XCPR(-1)) & $\begin{array}{r}-0.000031 * * \\
(-4.478)\end{array}$ & & \\
\hline CointEq(-1) & $\begin{array}{r}-0.522 * * * \\
(-8.842)\end{array}$ & & \\
\hline
\end{tabular}

NOTE: the figures reported are t-statistics in parenthesis and coefficients indicating the various level of significant with asterisked $(*)$ at $10 \% ;(* *)$ at $5 \%$ and $(* * *)$ at $1 \%$. 
Thus, this work provides another asymmetric channel that crime reduced economic growth. Similarly, Goulas and Zervoyianni (2015) obtained a negative impact of interaction crime with public-safety spending on growth and they revealed in their study that a higher public spending, that is, above the mean would cause strain on the public sector, which would be detrimental to economic growth.

Moreover, the short-run analysis of the two models indicates that crime affects economic growth negatively at 5\% level of significance. The accumulation of resources through education helps to improve economic growth at 5\% level of significance. While prosecution contributes to economic growth at $1 \%$, public expenditure on internal security was not significant. In addition, the error correction term $\left(E C T_{i-1}\right)$ of -0.522 and -0.376 is significant at $1 \%$. The significance of this $\left(E C T_{i-1}\right)$ shows that the feedback mechanism is effective in Nigeria in stabilizing the growth of the economy. This suggests that a deviation from the long-run equilibrium level of economic growth in one year is nearly corrected for by $52.2 \%$ and $37.6 \%$ in the following year in model 1 and 2 respectively.

\section{Conclusion}

The crime dependency on deterrence measures was examined on growth based on the interaction of crime with the prosecution and public expenditure on internal security. Thus, the idea is to see whether the crime is detrimental to economic growth. Besides, the result indicates that crime adversely and significantly affects economic growth both in the long-run and short-run. In addition, this study finds that crime imposes a tax of prosecution and public expenditure on internal security on the country. The tax of prosecution and public expenditure on internal security occurs in the attempts to curb crime. In spite of curbing crime through these deterrence measures, the study finds that deterrence measures in Nigeria when depended on would not improve economic growth especially in the long-run. This is because crime interaction with deterrence measures through the mean is impacting on growth negatively in the long-run. Firstly, when a crime interacts with prosecution, and is accessed by means of prosecution, economic growth is significantly reduced. This means that the state of crime prosecution in the country is not sufficient to promote economic growth in the long-run. This is because crime is not well prosecuted in the country due to poor investigation and delay in justice which has led to long waiting cases in the country (Agbonika, 2014). Secondly, when a crime interacts with public expenditure on internal security, and is accessed by means of public expenditure on internal security, economic growth is significantly reduced. This result supports the assertion that funds meant for security have not been properly utilized due to the absence of legislation backing 
accountability of security funds in Nigeria (Egbo, Nwakoby, Onwumere, \& Uche, 2012).

Thus, this study suggests enactment of law supporting accountability of security funds especially money disbursement as security votes to political office holders. This would further strengthen deterrence in institutions like the Nigeria Police and Judiciary to perform better. Moreover, this would help the country to reduce the congestion of prison inmates and thus save cost as the prompt prosecution would discourage long waiting trial that keeps offenders for a long time in prison without trial. Similarly, Ostermann and Chaplain (2016) believed that much effort should be put into reducing criminal recidivism in order to save cost.

Moreover, this study informs that there are many ways that government deters crime which include fine and imprisonment, but this study only considers prosecution alongside with public security funds. Therefore, further studies are required to give consideration to other deterrence measures not discussed here.

\section{References}

1. Abu, N., Abd Karim, M., Z., \& Aziz, M. I. A. (2015). Low savings rates in the economic community of West African States (ECOWAS): the role of corruption. Journal of Economic Cooperation and Development 36, no. 2, pp.63-90.

2. Agbonika, J. A. M. (2014). Delay in the Administration of Criminal Justice in Nigeria: Issues from a Nigerian Viewpoint. Journal of Law, Policy and Globalization, 26, pp.130138.

3. Badiora, A., Israel, O., Olasunkanmi, H., \& Ojewale, O. S. (2014). Crime statistics in a Nigerian Traditional City: A Geographic Analysis. Journal of Asian and African Studies, pp.1-15.

4. Batabyal, S., \& Chowdhury, A. (2015). Curbing corruption, financial development and income inequality. Progress in Development Studies 15, no. 1, pp.49-72.

5. Becker, G. S. (1968). Crime and punishment: An economic approach. Journal of Political Economy 66, no. 2, pp.169-21.

6. Bodman, P. M., \& Maultby, C. (1997). Crime, punishment and deterrence in Australia. International Journal of Social Economics 24, no 7/8/9, pp.884 - 901.

7. Central Bank of Nigeria. (2013). Central Bank of Nigeria Annual Report.The federal Republic of Nigeria.

8. Detotto, C., \& Pulina, M. (2012). Does more crime mean fewer jobs and less economic growth? European Journal of Law and Economics 36, no. 1, pp.183-207.

9. Dima, S. (2014). The link between globalisation, economic growth and education: an analysis in the case of Romania. Studia Universitatis "Vasile Goldis" Arad Economics Series, 24, Issue 4, pp.94-103.

10. Egbo, O., Nwakoby, I., Onwumere, J., \& Uche, C. (2012). Security votes in Nigeria: disguising stealing from the public purse. African Affairs, 00/00, 1-18. 
11. Ehrlich, I. (1973). Participation in illegitimate activities: A theoretical and empirical investigation. The Journal of Political Economy 81, no. 3, pp.521-565.

12. Enamorado, T., López-Calva, L., F., \& Rodríguez-Castelán, C. (2014). Crime and growth convergence: Evidence from Mexico. Economics Letters 125, pp.9-13.

13. Engle, R. F., \& Granger, C. W. J. (1987). Co-Integration and error correction: representation, estimation, and testing. Econometrica 55, no. 2, pp.251-276.

14. Federal Ministry of Finance, Nigeria (FMFN). (2014). Challenges of budget 2013 implementation in budget 2014 -"A Budget for Jobs and Inclusive Growth", http://www.budgetoffice.gov.ng/index.php/component/content/article/78-geral-

information/72-budget, accessed on16 June 2014.

15. Goulas, E., \& Zervoyianni, A. (2015). Economic growth and crime: is there an asymmetric relationship? Economic Modelling 49, pp.286 -295.

16. Halicioglu, F. (2012). Temporal causality and the dynamics of crime in Turkey. International Journal of Social Economics 39, no. 9, pp.704 - 720.

17. Halicioglu, F., Andrés, A. R., \& Yamamura, E. (2012). Modeling crime in Japan. Economic Modelling 29, no. 5, pp.1640-1645.

18. Japan International Cooperation Agency (JICA). (2011). The federal Republic of Nigeria Study for Poverty Profile (Africa) Final Report. Mitsubishi UFJ Research and Consulting Co. Ltd.

19. Mauro, L., \& Carmeci, G. (2007). A poverty trap of crime and unemployment. Review of Development Economics 11, no. 3, pp.450-462.

20. Narayan, P. K. (2005). The saving and investment nexus for China: evidence from cointegration tests. Applied Economics 37, pp.1979-1990.

21. National Bureau of Statistics. (2011). Annual Abstract of Statistics. The Federal Republic of Nigeria.

22. National Bureau of Statistics. (2012). Social Statistics in Nigeria. The Federal Republic of Nigeria.

23. Network on Police Reform in Nigeria (NOPRIN). (2010). Criminal Force Torture, Abuse, and Extrajudicial Killings by the Nigeria Police Force. Open Society Institute, New York.

24. Ojedokun, U. A. (2014). Contributing Factors to Police Homicide in Nigeria. Police Journal: Theory, Practice and Principles 87, pp.41-48.

25. Ouimet, M. (2012). A World of Homicides: The Effect of Economic Development, Income Inequality, and Excess Infant Mortality on the Homicide Rate for 165 Countries in 2010. Homicide Studies 16, no. 3, pp.238-258.

26. Pesaran, B., \& Pesaran, M., H. (2009). Time series econometrics using micro fit 5.0. Oxford University Press, Oxford.

27. Pesaran, M., H., Shin, Y., \& Smith, R., J. (2001). Bounds testing approaches to the analysis of level relationships. Journal of Applied Econometrics 16, pp.289-326.

28. Pribac, L. I., Anghelina A., \& Blaga R. L. (2016). Return on investment in education. Case study on education in Romania. Studia Universitatis “Vasile Goldis" Arad Economics Series, 26, Issue 1, pp.26-39.

Studia Universitatis "Vasile Goldis" Arad. Economics Series Vol 26 Issue 4/2016 ISSN: 1584-2339; (online) ISSN: 2285 - 3065

Web: publicatii.uvvg.ro/index.php/studiaeconomia.Pages $24-40$ 
29. Shyh-Wei, C. (2009). Investigating causality among unemployment, income and crime in Taiwan: evidence from the bounds test approach. Journal of Chinese Economic and Business Studies 7, no. 1, pp.115-125.

30. Stigler, G. J. (1974). The optimum enforcement of laws- essays in the economics of crime and punishment. Journal of Political Economy 78, pp.526-536.

31. Svensson, R. (2013). An Examination of the Interaction between morality and deterrence in Offending: A Research Note. Crime \& Delinquency XX, no. X, pp.1-16. 32. Vigne, N. L., \& Samuels, J. (2012). The Growth \& Increasing Cost of the Federal Prison System: Drivers and Potential Solutions. Urban Institute: Justice Policy Centre. http://www.urban.org/research/publication/growth-increasing-cost-federal-prison-systemdrivers-and-potential-solutions accessed 12 August 2015.

33. Witt, R., \& Witte, A. (2000). Crime, Prison, and Female Labor Supply. Journal of Quantitative Criminology 16, no. 1, pp.69-85.

33. World Bank. (2014). World Bank Indicator for Development. http://data.worldbank.org/data-catalog/world development-indicator accessed 4August 2014. 